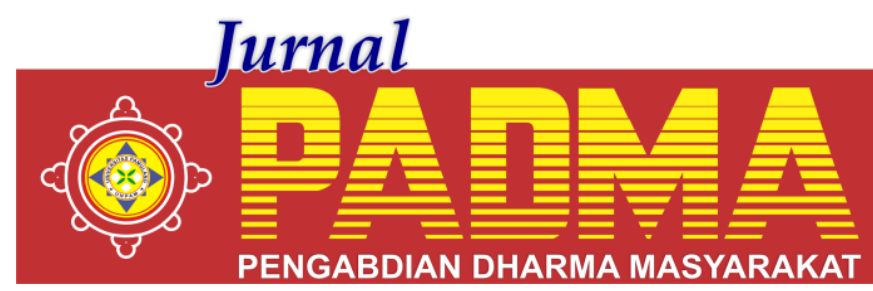

VOLUME 1, NOMOR 2, APRIL 2021

\title{
IMPLEMENTASI PENGGUNAAN TEKNOLOGI INFORMASI DAN KOMUNIKASI DALAM SISTEM MANAJEMEN PEMBELAJARAN PADA MASA PANDEMI COVID-19 DI YAYASAN PENDIDIKAN ISLAM NURUL AMAL
}

\author{
${ }^{1 *}$ Imas Masriah, ${ }^{2}$ Wily Sumantri, ${ }^{3}$ Soemarno Syafi'i, ${ }^{4}$ Sifa Fajriyah, ${ }^{5}$ Eka Safrudin, \\ 6Purti Diana Sri Utari \\ Universitas Pamulang, Tangerang Selatan, Banten, Indonesia \\ *dosen02036@unpam.ac.id
}

\begin{abstract}
Abstrak
Banyak dari masyarakat menerima begitu saja teknologi informasi dan komunikasi modern yang bahkan tidak dapat diakses beberapa dekade lalu. Inovasi-inovasi teknologi informasi dan komunikasi ini, telah lama dianggap sebagai hal tidak penting, selama masa tenang kini menjadi sangat diperlukan dalam menghadapi pandemi COVID-19. Sekarang telah ada berbagai teknologi digital yang dapat digunakan untuk menambah dan meningkatkan strategi pekerjaan, pembelajaraan dan kesehatan masyarakat. Selama pandemi COVID-19, teknologi memainkan peran penting dalam menjaga kegiatan masyarakat tetap berfungsi pada saat Pembatasan Sosial Berskala Besar (PSBB). Perkembangan teknologi informasi yang semakin pesat di era globalisasi saat ini tidak bisa dihindari lagi pengaruhnya terhadap dunia Pendidikan. Oleh sebab itu, Peran pendidik sangat berperan penting dalam pemanfaatan ICT dimana pendidik berperan sebagai desainer pembelajaran. Tujuan dari pengabdian kepada masyarakat ini adalah untuk mengetahui bagaimana dari sisi bidang pendidikan memanfaatkan teknologi informasi dan komunikasi sebagai media untuk meneruskan kegiatan yang tidak dapat dilakukan secara tatap muka dan teknologi yang dapat dimanfaatkan untuk kegiatan belajar dan mengajar di sekolah selama pandemi COVID-19. Metode penelitian ini dipaparkan secara deskriptif kualitatif. Penulis menggunakan teknik pengumpulan data observasi. Hasil yang diperoleh dari pertemuan yang dilakukan dalam pengabdian kepada masyarakat bagaimana bidang pendidikan memanfaatkan teknologi informasi dan komunikasi untuk kegiatan School From Home dan kepentingan manajemen pendidikan. Disimpulkan bahwa bidang pendidikan memanfaatkan teknologi informasi dan komunikasi untuk tetap melaksanakan kegiatan belajar mengajar menggunakan teknologi informasi dan komunikasi yang memiliki keunggulan dan kemudahan untuk dipergunakan oleh berbagai komponen pendidikan.
\end{abstract}

Kata Kunci : Bimbingan Teknis, Pemanfaatan Tekonologi ICT

\begin{abstract}
Many societies take for granted modern information and communication technology that was inaccessible even a few decades ago. Information and communication technology innovations that have been underestimated, have now become indispensable in the face of the COVID-19 pandemic. Currently, there are various digital technologies that can be used to add and improve work, learning and public health strategies. During the COVID-19 pandemic, technology plays an important role in keeping community activities functioning during Large-Scale Social Restrictions (PSBB). The development of information technology which is increasingly rapid in the current era of globalization cannot be avoided anymore its impact on the world of education. Therefore the role of educators plays an important role in the use of ICT where educators act as learning designers. The purpose of this community service is to find out how in terms of education, the use of information and communication technology as a medium for continuing activities that cannot be done faceto-face and technology that can be used for teaching and learning activities in Indonesia. Indonesia. schools during the COVID-19 pandemic. This research method is described in a qualitative descriptive. The author uses observational data collection techniques. The results obtained from the meetings held in community service are how the education sector makes use of information and communication technology for School From Home activities and for the benefit of educational management. It is concluded that the world of education makes use of information and communication technology to continue to carry out teaching and learning activities by utilizing information and communication technology which has advantages and ease for use by various components of education..
\end{abstract}

Keywords: Technical Guidance, Utilization of ICT Technology 


\section{PENDAHULUAN}

Dalam kondisi dunia dan juga Indonesia sedang menghadapi pandemi Virus Corona atau COVID-19 ini mengharuskan dunia pendidikan bertransformasi untuk mengikuti perubahan karena sistem pembelajaran yang digunakan selama ini adalah bertatap muka di kelas menjadi sistem daring (dalam jaringan) dengan memanfaatkan teknologi internet. Sistem informasi sebagai suatu sistem yang merupakan kumpulan elemen-elemen yang saling berinteraksi untuk mencapai tujuan tertentu, mempunyai beberapa komponen yang saling terkait dan membentuk jalinan kerja yang kompak untuk mencapai sasaran (Adisel, 2019).

Teknologi manajemen adalah input, proses dan output dari sistem. Manajemen ini termasuk menggunakan metode; hardware, software dan pengolahan berarti operasi seperti menghitung, kontrol, pengambilan keputusan, evaluasi dan penyaringan. Oleh karena itu era globalisasi saat ini, perkembangan teknologi informasi dan komunikasi yang semakin pesat dan telah merambah berbagai aspek kehidupan manusia, termasuk dalam dunia pendidikan di berbagai negara termasuk Indonesia. Bahkan adanya tekanan teknologi informasi dan komunikasi atau Information and Communication Technologies (ICT) yang sangat besar terhadap sistem pendidikan secara global karena teknologi yang berkembang menyediakan kesempatan yang sangat besar untuk mengembangkan manajemen pendidikan dan proses pembelajaran di perguruan tinggi (Wiliam, 2015).

ICT adalah sistem pembelajaran berbasis multimedia (teknologi yang melibatkan teks, gambar, suara, dan video) mampu membuat penyajian suatu topik bahasan menjadi menarik, tidak monoton dan mudah untuk dicerna. Disamping itu juga dengan digunakannya ICT maka proses pembelajaran tidak terbatas dalam kelas tertutup. Proses pembelajaran dapat dilakukan dimana pun, kapan pun dan oleh siapa pun; tidak terbatas oleh waktu dan ruang. Peran yang sangat penting dan strategis ini sebagai pusat belajar, pusat budaya, dan pusat peradaban menuntut lembaga-lembaga pendidikan untuk dapat mengembangkan aktivitas pembelajaran yang jelas dan daya jangkau yang luas. Namun tetap diingat bahwa ICT hanyalah sebagai alat bantu dalam proses pembelajaran. Menurut UNESCO (2011), ada lima manfaat yang dapat diraih melalui penerapan ICT dalam sistem pendidikan, yaitu: 1) mempermudah dan memperluas akses terhadap pendidikan, 2) meningkatkan kesetaraan pendidikan, 3) meningkatkan mutu pembelajaran, 4) meningkatkan profesionalisme guru dan 5) meningkatkan efektifitas dan efisiensi manajemen, tata kelola, dan administrasi pendidikan.

Mengetahui dan manyadari besarnya manfaat ICT bagi dunia pendidikan, para ahli UNESCO menganjurkan agar semua negara; khususnya negara berkembang; meningkatkan berbagai sumber daya yang diperlukan untuk mengelaborasi ICT dalam berbagai kebijakan, strategi, dan aktivitas pendidikan. Sekarang ini sebagian besar negara menekankan pembelajaran dan menerapkan teknologi informasi dan komunikasi sebagai inti dari sistem pendidikan mereka (Hasemy et al., 2012). Di Indonesia, berdasarkan Rencana Pembangunan Jangka Menengah Nasional (RPJM) 2020-2024 ditegaskan pada Perioritas Kemendikbud yang keempat adalah pengembangan teknologi. Fokus dari teknologi ini menurut Menteri adalah untuk membantu semua manusia dalam sestem untuk melaksanakan tugasnya dengan cara yang lebih baik. Kementerian Pendidikan dan Kebudayaan, untuk dapat memberikan pelayanan prima, salah satu yang perlu dilakukan adalah pengembangan teknologi informasi dan komunikasi (ICT) yang dilakukan melalui pendayagunaan ICT di bidang pendidikan yang mencakup peran ICT sebagai substansi pendidikan, alat bantu pembelajaran, fasilitas pendidikan, standar kompetensi, penunjang administrasi pendidikan, alat bantu manajemen satuan pendidikan, dan infrastruktur pendidikan.

Berkaitan dengan hal di atas, fenomena pemanfaatan ICT dalam pembelajaran di lembaga pendidikan semakin bergaung, bahkan dalam kurikulum 2013 ICT memegang peranan yang sangat penting dalam pelaksanaan pembelajaran. Pada kurikulum 2013 dijelaskan bahwa pembelajaran menerapkan prinsip siapa saja 
adalah guru, siapa saja adalah siswa, dan dimana saja adalah kelas. Oleh karena itu, pemanfaatan ICT diperlukan dalam rangka efektivitas dan efisiensi pembelajaran.

Agar peserta didik terbantu mengembangkan dan menyusun pengetahuan sendiri, tanpa langsung bimbingan guru, maka situasi belajar yang disediakan baginya haruslah konstruktivistik (Prawiradilaga, 2014). Peranan media digital dapat dimaksimalkan pemberdayaannya melalui desain pembelajaran, teori belajar, dan desain pesan sehingga dapat menghasilkan pengalaman belajar yang baik bagi peserta didik.

Namun pada kenyataannya, penerapan ICT dalam bidang pendidikan di Indonesia masih dalam tahap awal serta masih belum termanfaatkan secara maksimal dan merata. Kendala tersebut disebabkan antara lain oleh belum meratanya infrastruktur yang mendukung penerapan ICT di bidang pendidikan dan ketidaksiapan sumber daya manusia untuk memanfaatkan ICT dalam proses pembelajaran dengan kondisi pandemi COVID-19 ini mau tidak mau pendidik ataupun guru harus merubah cara dan system pembelajaran yang biasanya tatap muka beralih ke sistem daring.

Dari permasalahan diatas, adanya kebutuhan dari suatu permasalahan di sebuah sekolah Yayasan Pendidikan Islam Nurul Amal, maka kami selaku Mahasiswa yang berjumlah 5 orang mahasiswa dari pascasarjana Universitas Pamulang bermaksud menjalankan pengabdian kepada masyarakat sebagai wujud kami dalam menjalankan TRIDRAMA Perguruan Tinggi sekaligus menyelesaikan tugas perkuliahan mahasiswa S2 Manajemen Universitas Pamulang.

Yayasan Pendidikan Islam Nurul Amal selama ini belum banyak mengetahui bagaimana menciptakan ide-ide penggunaan teknologi informasi dalam sistem manajemen pembelajaran yang efektif pada masa pandemi COVID-19. Diharapkan dengan PKM ini dapat mewujudkan kemandirian pembiayaan di Yayasan Pendidikan Islam Nurul Amal.

\section{METODE}

Metode yang digunakan dalam pelaksanaan kegiatan penelitian ini adalah dengan memberikan pelatihan kepada guru di Yayasan Pendidikan Islam Nurul Amal. Dalam hal ini maka dalam pelaksanaan bimbingan teknis kepada 20 peserta di Yayasan Pendidikan Islam Nurul Amal dilakukan dengan metode sebagai berikut:

a. Penyampaian materi berupa powerpoint

b. Tanya jawab/Diskusi

Untuk melihat dan mengetahui keberhasilan dari bimbingan teknis, maka dilakukan evaluasi. Menurut Mathis dan Jackson (2002: 31) evaluasi pelatihan adalah membandingkan hasil-hasil setelah pelatihan dengan tujuan. Dalam hal ini evaluasi dilakukan melalui kuesioner.

Setelah dilakukan pengisian angket kuesioner oleh peserta pelatihan pada saat pelatihan telah berakhir maka Tim PKM mengumpulkan kembali angket yang telah dijawab oleh peserta pelatihan tersebut, yang kemudian seluruh jawaban responden diolah dan dianalisa.

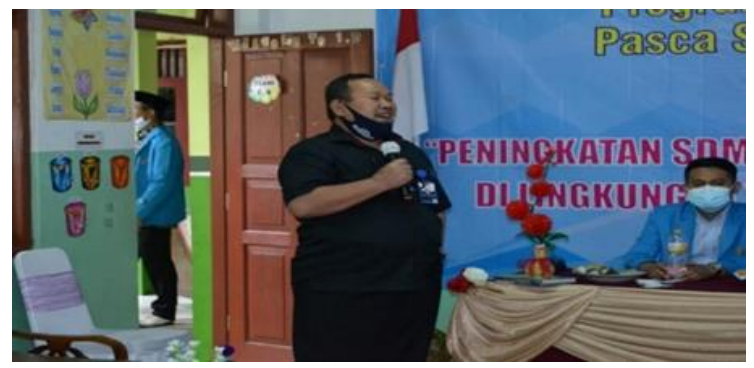

Gambar 1. Sambutan Dosen S2 Unpam

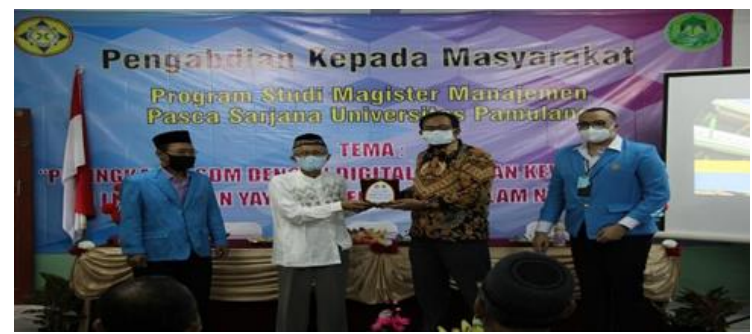

Gambar 2. Pemberian Plakat untuk Yayasaan

\section{HASIL DAN PEMBAHASAN}

Hasil Analisis Deskriptif atas jawaban sebanyak 20 sebagai peserta PKM setelah dilakukan bimbingan teknis terkait dengan pemahaman materi Pemanfaatan Teknologi ICT. Berdasarkan hasil Analisis Deskriptif atas jawaban peserta PKM terhadap materi tersebut, menunjukkan sebagai berikut:

1. Terkait tentang pemahaman peserta terhadap pentingnya pemanfaatan teknologi ICT pada masa Covid-19 mencapai 4,45 dengan katagori sangat 
paham. Hal ini berarti teknologi ICT sangat dibutuhkan peserta pada masa covid-19 dengan tujuan untuk mempermudah peserta didik belajar.

2. Terkait tentang pemahaman peserta dalam penerapan penggunaan teknologi ICT dalam pembelajaran mencapai 3,55 dengan katagori paham. Hal ini berarti ada peningkatan pemahaman peserta tentang cara menggunakan teknologi ICT, dibandingkan sebelum ada pelatihan kegiatan PKM, peserta belum mengenal teknologi ICT dan belum mengetahui cara memanfaatkan teknologi ICT dalam pembelajaran.

3. Terkait tentang pemahaman peserta dalam menghadapi kesulitan dalam menerapkan teknologi ICT mencapai 3,25 dengan katagori cukup paham. Hal ini banyak kendala dan kesulitan yang dihadapi peserta ketika dalam menerapakan teknologi ICT seperti kurangnya pemahaman dalam pengoperasian ICT, tidak alat ada pendukung sehingga ICT tidak bisa diterapkan.

4. Terkait dengan pemahaman peserta tentang pemanfaatan teknologi ICT sebagai media belajar mencapai 4,10 dengan katagori paham. Hal ini teknologi ICT dapat dijadikan sebagai media belajar pada masa Covid-19, karena dengan pemanfaatan media pembelajaran yang baik maka kualitas pembelajarannya dapat ditingkatkan dan bertujuan untuk mewujudkan efektifitas dan optimasi pembelajaran.

5. Terkait dengan pemahaman peserta mengenai perangkat teknologi ICT mencapai 4,15 dengan katagori paham. Hal ini berarti sekolah harus mendukung dengan menyediakan perangkat pendukung teknologi ICT agar dapat dimanfaatkan peserta ketika menerapakan ICT. Perangkat pendukung ICT seperti Komputer, Proyektor, aplikasi-aplikasi yang mendukung ICT dan internet.

6. Terkait pelatihan tentang teknologi ICT sangat bermanfaat bagi peserta mencapai 4,25 dengan katagori sangat paham. Hal ini berarti adanya peningkatan pemahaman peserta setelah dilakukan pemberian materi melalui kegiatan PKM.
Dengan demikian dapat disimpulkan adanya pengaruh yang signifikan sesudah pelaksanaan bimbingan teknis melalui kegiatan PKM yang dilakukan oleh mahasiswa Program Studi Megister Manajemen Univeritas Pamulang.

7. Terkait dengan pemahaman peserta menganai pemanfaatan teknologi ICT dapat meningkatkan hasil belajar dan kualitas pembelajaran mencapai 4,15 dengan katagori Paham. Sebelum pelatihan kegiatan PKM peserta dalam memberi pembelajaran masih sangat monoton dan kurang menarik bagi siswa dan berdampak pada hasil atau kualitas pembelajaran.

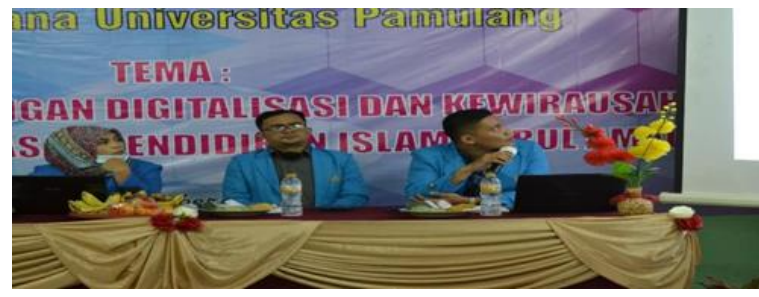

Gambar 3. Penyampaian Materi tentang Pemahamanan pemanfaataan teknologi ICT

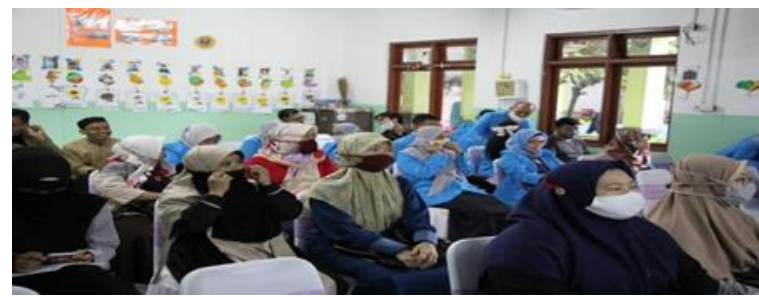

Gambar 4. Kegiatan sesi tanya jawab yang dilakukan peserta

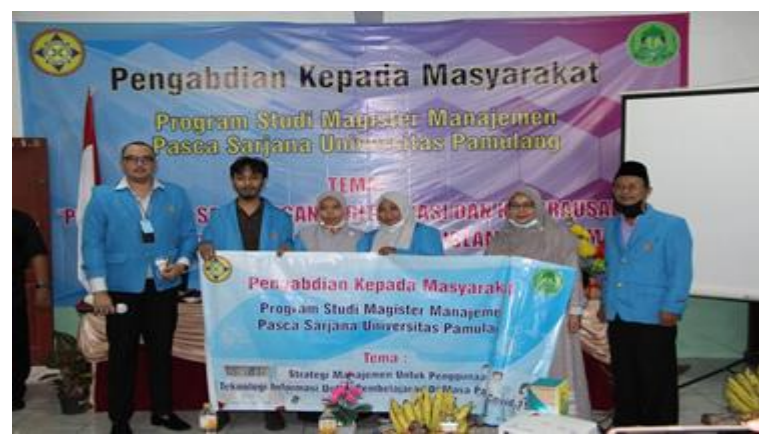

Gambar 5. Kelompok Mahasiswa dan dosen pembimbing yang mengadakan PKM

\section{PENUTUP}

Pemahaman peserta mengenai materi penerapan teknologi ICT dalam pembelajaran pada umumnya sudah paham. Namun ada beberapa kendala dalam penerapan teknologi ICT dikarenakan 
kurang adanya pendukung teknologi ICT sehingga teknologi ICT tidak dapat dioperasikan dengan baik.

Penerapan dan pemanfaatan teknologi ICT dapat membantu peserta dalam melakukan pembelajaran menjadi berkualitas, lebih cepat sehingga efektif dan efisien terutama pada masa pandemic covid19.

Peserta secara umum sudah memahami jenis-jenis pemanfaatan teknologi ICT dalam pembelajaran seperti sudah menggunakan power point, aplikasi zoom dan google classroom untuk mempermudah pembelajaran pada masa pandemic covid-19.

\section{DAFTAR PUSTAKA}

Adam, W. (2016). Student Perception on a Student Response System Formed by Combining Mobile Phone and a Polling Website. International Journal of Education and Development using Information and Communication Technology (IJEDICT), 12(1)

Adisel, A. (2019). Manajemen Sistem Informasi Pembelajaran. ALIGNMENT: Journal of Administration and Educational Management, 2(2), 105112

Education (Science Direct, Computer \& Education 50, 2008)

Evans, C. (2008). The Effectiveness of MLearning in the Form of Podcast Revision Lectures in Higher

Haque, M. G., Nurjaya, N., Affandi, A., Erlangga, H., \& Sunarsi, D. (2021). Micro Financial Sharia Non-bank Strategic Analysis: a Study at BMT Beringharjo, Yogyakarta. Budapest International Research and Critics Institute (BIRCI-Journal): Humanities and Social Sciences, 4(2), 1677-1686.
Hashemy, S. A., Hayati, D., \& Hashemy, Z. (2012). A Survey of the Application of Information Communication Technology in Education. International Journal of Information and Education Technology, 2(1)

Pima, J. M., Odetayo, M., Iqbal, R., \& Sedoyeka, E. (2016). Assessing the Available ICT Infrastructure for Collaborative Web Technologies in a Blended Learning Environment in Tanzania: A Mixed Methods Research. International Journal of Education and Development using Information and Communication Technology (IJEDICT), 12(1)

Prawiradilaga, D. S. (2014). Wawasan Teknologi Pendidikan. Jakarta: Kencana Prenada Media Group

Samuel, M., Mugoniwa, B., Furusa, S. S., \& Rebanowako, T. G. (2016). An Analysis of the Use of Cloud Computing among University Lecturers: A Case Study in Zimbabwe. International Journal of Education and Development using Information and Communication Technology (IJEDICT), 12(1)

Sutrisno, S., Abidin, A. Z., Winata, H., Harjianto, P., \& Sunarsi, D. (2020). Penyuluhan Pengelolaan covid Sederhana Siswa SMA 6 Tangerang Selatan. BAKTIMAS: Jurnal Pengabdian pada Masyarakat, 2(1), 67-71.

Unesco. (2011).Education for All Global Monitoring Report.

http://www.edukasi.kompas.com/rea d/2011/03/04463810/peringka.pendi dik an.indonesia.turun/

William, W. S., Forsman, A., \& Yan, J. (2015). An E-Curriculum Based Systematic Resource Integration Approach to Web-Based Education. International Journal of Information and Education Technology, 5(7). 